\title{
ASPEK MORAL DALAM NOVEL COMPLICATED KARYA THERESIA : TINJAUAN SOSIOLOGI SASTRA
}

\author{
Lita Mardiyah $^{1}$, Juidah Agustina ${ }^{2}$ \\ Litamardiyah98@gmail.com ${ }^{1}$,juaidah82@gmail.com² \\ Universitas PGRI Palembang
}

\begin{abstract}
Abstrak--Penelitian ini bertujuan untuk mengetahui dan mendeskripsikan aspek moral dalam novel Complicated karya Theresia :Tinjauan sosiologi sastra. Metode yang digunakan dalam penelitian ini adalah metode pendekatan kualitatif dengan metode deskriptif. Teknik pengumpulan data menggunakan teknik trianggulasi. Hasil penelitian yang dicapai dalam penelitian ini ada tiga. Pertama wujud aspek moral hubungan manusia dengan Tuhan yaitu :senantiasa berdoa kepada Tuhan dan bersyukur. Kedua, wujud aspek tokoh-tokoh hubungan manusia dengan dirinya sendiri yaitu :pintar, jujur, bertanggung jawab, kesedihan dan kemarahan. Ketiga, wujud aspek moral tokoh-tokoh hubungan manusia dengan masyarakat yaitu : peduli sesama, meminta maaf, kebersamaan.
\end{abstract}

Kata Kunci : Aspek moral, novel, sosiologi sastra

Abstract--This study aims to identify and describe the moral aspects of Theresia'sComplicated novel: An overview of the sociology of literature. The method used in this research is a qualitative approach with descriptive methods. Data collection techniques using triangulation techniques. There are three research results achieved in this study. The first is the form of the moral aspects of the human relationship with God, namely: always praying to God and giving thanks. Second, the form of aspects of human relationship figures with himself, namely: smart, honest, responsible, sad and angry. Third, the form of the moral aspects of the figures of human relations with society, namely: caring for others, apologizing, togetherness.

Keywords: moral aspects, novel, sociology of literature

Artikel Diterima:19-08-2020 Artikel Disetujui:26-02-2021 Artikel Dipublikasi:28-02-2021

Corresponden Author: Lita Mardiyah E-mail: litamardiyah98@gmail.com

DOI: http://dx.doi.org/10.31851/pembahsi.v11i1.4729

\section{PENDAHULUAN}

Sastra merupakan suatu hasil kegiatan kreatif manusia yang berupa ungkapan penghayatan tentang kehidupan menggunakan bahasa sebagai penyampainya kepada masyarakat luas. Sastra sebagai hasil karya seni manusia yang bisa berupa tulisan maupun lisan yang mempunyai makna atau keindahan tertentu sastra juga memberikan berbagai kisah yang merangsang pembaca untuk berbuat sesuatu.

Agustina (2017) mengatakan sastra salah satu cabang kesenian yang selalu berada dalam peradaban manusia semenjak ribuan tahun lalu. Kehadiran sastra ditengah peradapan manusia tidak dapat ditolak, bahkan kehadiran tersebut diterima sebagai salah satu realitas sosial budaya. Hingga saat ini, sastra tidak saja dinilai sebagai sebuah karya seni yang memiliki budi, imajinasi, dan emosi, tetapi telah dianggap sebagai suatu karya kreatif yang memanfaatkan sebagai konsumsi intelektual disamping emosi.

Karya sastra bukan hanya sekedar memberikan hiburan dan keindahan kepada pembaca namun karya sastra juga memberikan pengetahuan tentang nilai-nilai sastra seperti nilai pendidikan, moral, sosial, 
dan religius. Hal tersebut terjadi karena adanya karya sastra yang bersifat multidimensi yang mana didalamnya terdapat dimensi kehidupan contohnya saja karya sastra yang berupa novel.

Menurut Priyatni (2012) Kata novel berasal dari bahasa Latin novellus. Kata novellus dibentuk dari kata novus yang berarti baru atau new dalam bahasa inggris. Dikatakan baru karena bentuk novel adalah karya sastra yang datang kemudian dari bentuk karya sastra lainnya, yaitu puisi dan drama. Kehadiran bentuk novel sebagai salah satu bentuk karya sastra berawal dari kesusastraan Inggris pada awal abad ke-18.

Moral dalam karya sastra mencerminkan pandangan hidup pengarang yang bersangkutan, pandangannya tentang nilainilai kebenaran, dan hal itulah yang ingin disampaikannya kepada pembaca. Kamus Besar Bahasa Indonesia (2015) moral adalah ajaran baik buruk yang diterima umum mengenai perbuatan sikap kewajiban, akhlak budi pekerti susila kondisi mental yang membuat orang tetap berani bersemangat bergairah, berdisiplin, isi hati atau keadaan perasaan sebagaimana terungkap dalam perbuatan.

Secara institusional objek sosiologi dan sastra adalah manusia dalam masyarakat, sedangkan objek ilmu-ilmu kealaman adalah gejala-gejala alam. Menurut Ratna (2013) sosiologi sastra berasal dari kata sosiologi dan sastra. Sosiologi berasal dari akar kata sosio (Yunani) (socius berarti bersama-sama, bersatu, kawan, teman) dan logi (logos berarti sabda, perkataan, perumpamaan). Perkembangan berikutnya mengalami perubahan makna, soio/socius berarti masyarakat, logi/logos berarti ilmu.

Jadi sosiologi berarti ilmu mengenai asal-usul dan pertumbuhan (evolusi) masyarakat, sifatnya umum, rasional, dan empiris. Sastra dari akar kata sas (Sansekerta) berarti mengarahkan, mengajar memberi petunjuk dan instruksi. Akhiran tra berarti alat, sarana. Jadi sastra berarti kumpulan alat untuk mengajar buku petunjuk atau buku pengajaran yang baik.

Di dalam memahami sebuah novel, sama halnya dengan menghayati dunia hayalan yang diciptakan oleh seorang sastrawan, meskipun terkadang terbawa oleh setiap cerita-cerita yang ada didalam novel tersebut. Novel Complicated Karya Theresia dipilih dalam penelitian ini karena sangat menarik untuk dikaji.

Kelebihan novel ini terletak pada ceritanya, yakni tentang keteguhan dan pengalaman hidup yang dialami Clarensia Karenina Alexander (Karen) sebagai tokoh utama. Keteguhan hati tersebut terkadang harus dapat pertahanan ditengah realita kehidupan yang selalu berganti dan sangat kuat pengaruhnya terhadap keadaan yang dialami karen gadis remaja yang sedang melawan penyakit kronis sambil berusaha bertahan dari kebencian kakak kandungnya.

Karen sebagai tokoh utama dalam novel ini juga memiliki kelebihan dibalik keteguhan hatinya, dia memiliki sifat mandiri, bertangung jawab dan juga sabar 
sehingga dia masih suka memikirkan kakaknya walaupun kakaknya sangat membenci Karen, tetapi Karen tetap berbuat baik kepada kakaknya dan tidak pernah membalas kebencian kakanya. Kelebihan novel ini yaitu pengarang dapat menceritakan atau menggambarkan secara detail setiap kejadian-kejadian yang ada dengan menggunakan kata-kata yang jelas, sehingga pembaca dapat ikut larut dan terbawa dalam kisah tersebut.

Novel Complicated karya Theresia dalam hal ini dapat dianggap sebagai karya sastra yang baik karena di dalamnya mengandung pesan moral yang ditampilkan lewat tokoh-tokoh dan pembaca dapat mengambilnya sebagai teladan. Dengan adanya karya sastra yang memberikan nilai moral. penulis merasa tertarik untuk mengkaji aspek moral yang terdapat dalam novel Complicated karya Theresia.

Ketertarikan penulis berdasarkan anggapan bahwa moral merupakan aspek yang penting dalam suatu karya sastra karena dengan adanya nilai moral dalam karya sastra, dapat memberikan pendidikan yang mampu memperkaya rohaniah dan memberikan pengaruh terhadap prilaku pembaca baik yang bersifat positif maupun negatif.

Pemilihan novel Complicated karya Theresia sebagai bahan penelitian karena ceritanya banyak menampilkan persoalan hidup dan kehidupan yang menarik, serta banyak terdapat nilai moral yang sangat bermanfaat bagi pembaca. Cerita remaja yang menampilkan berbagai aspek kehidupan dan permasalahannya disampaikan dengan bahasa yang menarik dan mudah dipahami, dengan demikan akan memudahkan pembaca untuk menemukan nilai moral yang dimaksud Pemilihan novel Complicated karya Theresia sebagai bahan penelitian merupakan hal yang tepat untuk menyampaikan nilai-nilai moral kepada pembaca.

\section{METODE PENELITIAN}

Menurut Sugiyono (2015) metode penelitian pada dasarnya merupakan cara ilmiah untuk mendapatkan data dan kegunaan tertentu. Metode yang digunakan dalam penelitian ini adalah metode pendekatan kualitatif dengan metode deskriptif. Metode deskriptif merupakan metode yang dapat memecahkan atau menjawab permasalahan yang dihadapi dengan cara mengumpulkan data dan membuat kesimpulan.

Sumber data Arikunto Mengatakan bahwa yang dimaksud dengan sumber data adalah subjek dari mana data diperoleh. Sumber data dalam penelitian ini adalah novel Complicated karya Theresia. Menurut Sugiyono (2015) Teknik pengumpulan data merupakan langkah yang paling strategis dalam penelitian, karena tujuan utama dari penelitian adalah mendapatkan data. Teknik pengumpulan data yang digunakan dalam peneltian ini adalah teknik dokumentasi. Arikunto (2010)metode dokumentasi yaitu mencari data mengenai hal-hal atau variabel yang berupa catatan, transkrip, buku, surat kabar, majalah, 
prasasti, notulen rapat, lengger, agenda, dan sebagainya.

Dokumentasi utama yang penulis gunakan dalam penelitian ini adalah novel Complicated KaryaTheresia. Teknik analisis data yang digunakan dalam penelitian ini adalah teknik analisis konten. Menurut Endraswara (2013) analisis konten adalah strategi untuk menangkap pesan karya sastra. Tujuan analisis konten adalah membuat inferensi. Inferensi diperoleh melalui identifikasi dan penafsiran. Inferensi juga berdasarkan konteks yang melingkupi karya sastra. Adapunlangkah-langkah yang digunakanpenulisdalammengumpulkan data adalahsebagaiberikut.

1. Membaca novel Complicated karya Theresia secara keseluruhan.

2. Membaca ulang novel tersebut serta lebih cermat guna untuk memahami isi novel secara keseluruhan.

3. Membuat sinopsis novel Complicated.

4. Meganalisis hal yang berhubungan dengan aspek moral dan tinjauan sosiologi sastra.

5. Menginterpretasikan dan mendeskripsikan hasil analisis disertai dengan kutipan.

6. Menyimpulkan hasil

7. penelitian.

\section{HASIL DAN PEMBAHASAN}

Wujud aspek moral tokoh-tokoh dalam hubungan manusia dengan tuhan.

1. Senantiasa berdoa kepada Tuhan

Berdoa artinya memohon segala sesuatu kepada tuhan, baik itu permohanan untuk keselamatan diri sendiri maupun untuk orang lain. Dalam novel ini moral yang berhubungan dengan doa kepada tuhan tampak pada tokoh Nathanael Gabriel Alexander sebagai berikut.
"Sayang sama seseorang bukan berarti kita selalu nurutin segala kemauannya. Tapi juga mikirin apa yang baik buat dia. Sama kaya berdoa. Tuhan nggak selalu ngasih apa yang kalian mau, karena Tuhan punya rencana terbaik buat kalian".(hlm, 75)

Dari kutipan di atas menjelaskan bahwa papa Nath menjelaskan kepada dodit bahwa sesayang-sayangnya kita kepada sesorang bukan berarti kita harus menurutin semua yang orang itu minta. Sama halnya tedengan Tuhan sesayang-sayangnya Tuhan kepada hambanya ia tidak akan mengabulkan doa hambanya kalau itu tidak baik menurutnya.

"papa kenapa...?" tuntut
Nath. Dalam hati, ia berdoa
sekeras mungkin untuk
kemungkinan terbaik".(hlm,
85)

Pada kutipan di atas jelas menunjukkan bahwa nath berusaha berdoa dan berpikir positif bahwa kejadian yang menimpa papanya tidak akan pernah terjadi.

\section{Bersyukur}

Bersyukur artinya menerima segala apapun yang diberikan tuhan, menjalani kehidupan yang sudah ditentukan oleh tuhan dengan tabah ikhlas dan sabar.
"pekikan penuh rasa syukur langsung terdengar ketika seorang petugas pemadamkeluar menembus api. Di dalam pelukkannya ada, seorang anak laki-laki. Nama anak 
itu, Nathanael Gabriel

Alexander'.(hlm,1)

Dari kutipan di atas di jelaskan bahwa papa Nath sangat bersyukur ketika pemadam kebakaran berhasil menyelamatkan anaknya yang bernama Nath dari kebakaran rumah mereka.

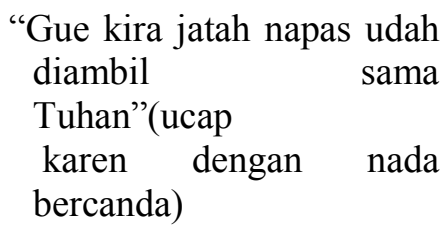

(Gabi terkekeh). "lo kenapa tadi? Diapain sama Nath?"

Tatapan Karen tampak menerawang sebentar. Lalu ia tersenyum lemah, dan lahi-lagi bicara nada bercanda.

"ngebut-ngebutan asli deh Gab, gue deg-degan banget".(hlm, 15)

Pada kutipan di atas menjelaskan bahwa karen sangat bersyukur karena dia bisa selamat dari aksi ngebut-ngebutannya Nath dan karena Karen tidak mau membuat temannya Gabi kepikiran atas perbuatan Nath Jadi Karen berusaha menjelaskan kepada temannya Gabi bahwa ia tidak apa-apa sambil bercanda.

Wujud aspek moral tokoh-tokoh hubungan manusia dengan diri sendiri

1. Pintar

Pintar memiliki dua makna yang saling berhubungan, yaitu pintar yang berkaitan dengan pikiran dan pintar yang berkaitan dengaan kemampuan atau non akademik. Keduanya saling berkaitan dengan kecerdasan otak. Pintar berhubungan dengan akademik yang memuaskan. Sedangkan pintar dalam kemampuan berhubungan dengan kinerja seseorang yang dinilai terbaik dari berbagai pandangan. Pintar dalam bidang akademik dapat dilihat dari tokoh karen pada kutipan berikut ini.

$$
\begin{array}{lr}
\text { "Meski lebih muda dari nath, } \\
\text { karen saat ini belajar } \\
\text { diangkatan yang sama } \\
\text { dengan nath karena berhasil } \\
\text { menembus } \\
\text { akselerasi".(hlm, 12). }
\end{array}
$$

Kutipan diatas jelas menunjukkan kepintaran karen dibidang akademik karena walaupun umurnya lebih muda dari kakaknya dan sering sakit-sakitan tapi dia mampu menembus kelas akselerasi atau kelas yang khusus untuk program belajar mengajar yang dibuat sedemikian rupa dan hanya untuk anak-anak yang intelegensian tinggi dan kreativitas dan motivasi yang tinggi pula yang bisa masuk kelas tersebut.

Selain tokoh di atas tokoh nath juga memiliki kepintaran di dalam bidang non akademik. Seperti kutipan berikut ini

$$
\begin{array}{lrr}
\text { “nath dipanggil } & \text { sebagai } \\
\text { perwakilan tim } & \text { basket } \\
\text { yang menjuarai } & \text { cup di } \\
\text { salah satu } & \text { sekolah } \\
\text { ternama. Para } & \text { murid } \\
\text { terutama para } & \text { siswi } \\
\text { bersorak penuh sukacita } \\
\text { saat nath maju menerima } \\
\text { piala"(hlm,17) }
\end{array}
$$

Dari kutipan di atas dapat dilihat bahwa nath juga memiliki prestasi di bidang non akademik terbukti bahwa dia bisa memenangkan pertandingan basket antar sekolah. Dan nath juga banyak dikagumi teman-temannya karena prestasinya.

\section{Jujur}


Moral yang dapat mewujudkan norma untuk memberikan petunjuk supaya manusia selalu melakukan hal-hal yang berhubungan dengan kebaikan.manusia membutuhkan kejujuran saat berbicara mengenai apa yang telah dilakukan. Karena jujur adalah sikap yang menunjukkan kebesaran hati dan kelapangan dada manusia. Karena kejujuran merupakan modal utama dalam kehidupan sosial. Oleh sebab itu saat manusia ingin jujur berarti dia mengatakan sesuai kenyataan yang terjadi. Seperti kutipan berikut ini.

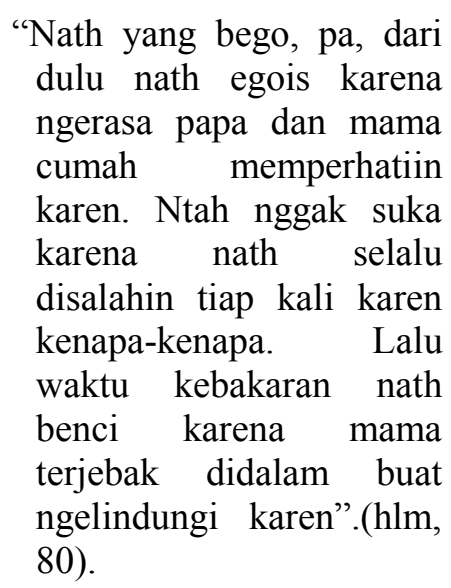

Dari kutipan diatas dapat dilihat bahwa setelah sekian lama nath memendam alasan dia membenci karen namun pada akhirnya dia tetap bercerita kepada papa nya dengan jujur. walaupun kejujuran nath sangat menyakitkan tapi dengan kejujuran papa nath dan karen bisa meluruskan kesalah pahaman antara kakak beradik itu.

\section{Bertanggung jawab}

Bertanggung jawab merupakan sikap untuk menjaga amanat yang telah diberikan orang lain dan jika melakukan kelalaian terhadap amanat tersebut harus siap menanggung hukuman. Tanggung jawab sangat di perlukan didalam menjalani kehidupan di dalam masyarakat. Sikap tanggung jawab dapat dilihat pada kutipan berikut.
"meski opa sudah menyuruh dodit untuk pulang karena besok sekolah, tetapi dodit tetap bersihkeras menunggui karen hingga gadis itu tersada, sebagai bentuk tanggung jawab katanya".(hlm, 77)
Dari kutipan diatas dapat dilihat bentuk tanggung jawab dodit kepada karen karena dodit merasa bersalah atas sakitnya karen sehingga dodit tetap bersih keras ingin menjaga karen sampai tersadar.
"titip karen ya, nath" (kata papa sambil menepuk-nepuk pundak nath).
Wajah datar nath berkedut sedikit demi sedikit.
"nanti gue yang nemanin karen" potong nath cepat.
Dodit bengong, lorong rumah sakit mendadak hening seluruh dunia seakan mendadak berhenti, untuk beberapa saat mulut dodit hanya menutup dan membuka tanpa suara seperti ikan mas kekurangan air.
“Lo.....apa?"(dodit berkata terbata-bata
Ngakk bakal gue ulang sahu,(sahut nath, mulai terdengar kesal.(hlm,83)
Dari kutipan di atas jelas sekali bahwa nath masih kesal dengan karen,dan dodit pun sangat terkejut melihat perubahan nath. Walaupun masih terlihat jelas kalau dia masih kesal dengan karen tetapi dia tetap mau bertanggung jawab menjaga karen dirumah sakit, walaupun itu papanya yang meminta nath untuk menjaga adiknya. 
"hari ini lo pulang kan? (nath menghela nafas panjang)"

"Pulang dong, please.

Barusan opa berangkat

dinas. Gue sendirian

dirumah. Butuh teman ngobrol"

"Tunggu. habis ini gue pulang"

"karen semdirian soalnya. Gue mesti pulang"

Katanya butuh teman ngobrol”.(hlm,144)

Dari kutipan diatas menunjukkan bahwa walaupun nath pernah sangat membenci adiknya tapi seiring dengan berjalannya waktu nath mampu mampu untuk melunakkan ego nya. Dan dari percakapan di atas terlihat jelas nath sudah mulai bertanggung jawab kepada adiknya. Dan bahkan walaupun pada saat itu nath sedang asyik mengobrol bersama teman-temannya tetapi dia rela untuk pulang lebih dulu demi sang adik.

\section{Kesedihan}

Kesedihan merupakan suatu perasaan yang dimana seseorang sedang mengalami suatu masalah. Kesedihan adalah masalah yang sering di hadapi oleh manusia didalam kehidupan. Seperti pada kutipan berikut.

Nath masih diam di
tempat, merasa
kehilangan arah. Ditempat
begitu banyak orang ini,
ia merasa kesepian.
Beberapa kerabat datang
dan menyampaikan bela
sungkawa kepadanya.
Nath hanya bisa
mengangguk pelanm
sebagai reaksi, tak mampu
mengucapkan kalimat
sepatah pun. Nath ingin

sekali berdiri tegar seperti opa dan uncle dave, tapi wajah kedua pria itu sangat mirip dengan papa, memicu kenangan yang menghantui nath sejak kemarin. Harapan kosong bahwa papa akan muncul dari pindu sambil berseru,"surprise!" mulai timbul dalam benak nath, tapi harapan tinggal harapan. Kematian adalah fakta tak terbantahkan.(hlm 94)

Pada kutipan di atas juga menjelaskan tentang kesedihan nath yang sangat terpukul karena kepergian papanya. Nath masih belum bisa menerima untuk kehilangan papanya karena di usia nath yang masih remaja ia harus berkali-kali merasakan di tinggalkan oleh orang-orang yang dia sayang dan dia harus menerima kenyataan pahit bahwa dia dan karen sekarang menjadi anak yatim piatu.

\section{Kemarahan}

Kemarahan merupakan suatu sikap seseorang yang memiiki jiwa emosional tinggi. Kemarahan yaitu sikap manusia yang sedang mengalami kebencian kepada sesuatu yang menurutnya tidak disukai atau tidak sesuai dengan yang ia harapkan. Kemarahan yang meluap pada novel ini dapat di lihat pada kutipan berikut ini.

\footnotetext{
"opa ingat kamu punya janji nggak akan berantem lagi”(opa ucap) " kamu pikir opa ucap) “ kamu pikir antem kaya gitu bakal nyelesain masalah?"'(tanya opa) (nath mulai buka suara). “ terpaksa. Opa sendiri dengar rekaman vano ngomong apa aja?"
} 
"orang bisa ngomong apa aja, tapi keputusan angkat tinju atau nggak itu keputusan kamu sendiri,"(tukas opa cepat) "kamu mau jadi jagoan? kalau mau begitu, nggak usah sekolah di sekolah saya. Sayan akan carikan kamu sekolah lain yang lebih bebas. Kamu bisa berantem kapan pun dan nggak akan jadi apa-apa." (hlm, 137)

PLAK!

Bunyi tamparan itu seakan membuat waktu berhenti. Nath terpaku di tempatnya. Pipi yang harusnya terasa skit itu, mendadak mati rasa. Seluruh tubuh nath kebas. Pikirannya mendadak kosong.

selalu saja, kamu selalu saja bikin ulah nath. Buat apa ngajak karen ke puncak, padahal kamu tahu kondisinya udah makin lemah? Jadinya ya begini. Kalo udah begini siapa yang mau tanggung jawab? Kamu kira nyawa adik kamu ringan, hah? Seringan kamu bikin ribut di sekolah? (Cecar opa) (hlm, 160)

$\begin{array}{cccc}\text { Dari } & \text { Kedua kutipan di atas } \\ \text { menjelaskan } & \text { tentang kekecewaan } & \text { dan }\end{array}$ kemarahan opa kepada nath walaupun sebetulnya bukan termasuk kesalahan nath semua tetapi karena opa adalah orang yang tingkat emosionalnya tinggi jadi dia tidak mau mendengarkan penjelasan terlebih dahulu. Dan karena opa yang selalu punya aura otoritas itulah yang membuat opa sulit akrab dengan siapa pun termasuk dengan nath.
Wujud nilai moral tokoh-tokoh hubungan manusia dengan masyarakat.

\section{Peduli sesama}

Moral peduli sesama adalah sebagian dari wujud empati kepada seseorang. Dan peduli biasanya ditunjukkan dengan saling mengingatkan saat melakukan sesuatu atau pun berbuat sesuatu. Sikap peduli sesama dalam novel ini ditunjukkan oleh gabi. Seperti kutipan dibawah ini.

\footnotetext{
"Gue mau lo minta maaf sama karen"(ucap gabi) tadi karen menangis dia cerita sama gue. Kenapa sih, lo tega banget ngomong gitu. Harusnya lo jadi sumber semangat buat karen. Nggak ngerti gue sam jalan pikir lo".(hlm, 22)
}

Berdasarkan kutipan di atas terlihat jelas bahwa gabi ingin melindungi karen dan dia tidak mau melihat temannya dibenci oleh kakak kandungnya.
"lo nggak kasian sama dia?" (tanya gabi)
nath menghela nafas dengan kasar. "B aja." Jawaban itu membuat gabi geregetan sendiri "coba lo bayangin, gimana rasa nya jadi dia. Setiap hari di bentak sama kakaknya sendiri. Udah gitu bokap lo orang sibuk, jadi nggak bisa selalu nemanin karen bolak-balik Rs. Bayangin gimana perasaan dia ke Rs sendirian, sementara kakaknya nggak jelas ke mana! Di saat-saat kayak gitu, yang harusnya berperan itu lo 


\begin{abstract}
sebagai kakaknya.
Sadar"

Saat nath tak kunjung

menyahut, gabi

melanjutkan kata-

katanya, "lo tahu kan,

karen nggak bisa diajak

ngebut? Lo lihat sendiri

kan, tadi pagi dia jadi

gimana?"

"udah telat,"(jawab nath

santai, seolah

perbuatannya tidak

berdampak apa-apa.

"alasan! Dia itu adik lo

nath!kenapa sih lo kayak

gitu amat ke dia ? salah

dia apa?"( hlm, 24)
\end{abstract}

Dari kutipan di atas sangat jelas terlihat bahwa gabi sangat menyayangi karen dan dia sudah mengganggap karen seperti adiknya kandungnya sendiri. Sehingga dia tidak mau melihat kalau karen harus di sakitan apalagi sampai harus dibenci oleh kakak kandungnya sendiri, apalagi gabi tau kalau karen sedang berusaha untuk melawan penyakit kronisnya dan di saat-saat seperti ini lah karen membutuhkan dukukungan, perhatian dan kasih sayang dari orang-orang terdekat.

\section{Meminta maaf}

Meminta maaf merupakan sikap yang menunjukkan bahwa seseorang yang sangat berbesar hati. Karena orang yang terlebih duhulu meminta maaf bukan berarti bahwa dia yang berbuat salah tetapi terkandang seseorang yang meminta maaf terlebih dahulu merupakan orang yang cinta kedamaian sehingga dia tidak mau berlarutlarut dalam suatu masalah.
Sikap meminta maaf dalam novel ini ditunjukkan oleh karen. Seperti pada kutipan berikut.

"maaf kemarin udah bikin lo telat. Lo nggak bakal ngebut kaya gitu kalau nggak hampir telat. Itu salah gue. maaf ya. Kalau udah bikin lo nggak nyaman." (hal,33)

"mending lo bisa main. Kalo nggak bisa ya ngga usah."

(Gabi terlihat geram). (Dodit menggeleng dengan ekspresi tidak setuju).

(Karen menunduk, kemudian lirih berkata), “ maaf gue nggak bermaksud..."

"maaf mulu lo. Jadi benar juga nggak,"

(dodit mulai panas)

"nath apa sih ngomongnya?

Nggak usah begitu

bangetlah."(hlm,59)

Dari kedua kutipan di atas menunjukkan bahwa karen sangat murah hati. Padahal pada kedua kutipan di atas sebenarnya nath yang berbuat salah kepada karen karena pada saat mereka mau berangkat kesekolah nath yang mengajak karen untuk mengebut sehingga menyebabkan penyakit karen kumat dan mimisan. Dan karen pun sudah tau kalau kakaknya memang sangat membencinya sejak lama sehingga dia sangat tau betul bahwa jangan kan untuk mengobrol dengan karen untuk duduk berdekatanpun nath merasa tidak nyaman. Tetapi disana karen masih tetap berharap jika kakak nya mau membukakan pintu hatinya agar mau memaafkan karen. Sehingga dia berulangulang kali mengucapkan kata maaf kepada kakaknya.. 
Sikap meminta maaf yang ditunjukkan oleh karen juga tercermin dalam tokoh nath. Walaupun nath dulu sangat membenci karen tapi seiring dengan berjalannya waktu dia mulai menyesali perbuatannya selama ini kepada karen.

“maaf gara-gara kelalaian
nath, karen jadi drop
lagi,"(kata nath perlahan.
Tatapannya tidak
menyiratkan kemarahan,
maupun protes keras.
Hanya ada ketenangan di
sana. Ketenangan yang
lahir dari rasa taggung
jawab).
"tapi kalau opa tanya buat
apa aku ajak karen jalan,
itu karena aku pengen
ajak karen senang-senang
sebelum udah benar-benar
nggak bisa apa-apa
selama badannya masih
bisa. Aku mau bikin dia
semangat buat terus hidup
itu yang mungkin bisa
ngalahin penyakit
karen".(hlm, 161)

Kutipan di atas jelas menunjukkan bahwa nath meminta maaf kepada opa karena nath telah mengajak karen dan teman-teman mereka kepuncak. Sehingga membuat badan karen kembali drop. Akan Tetapi nath mengajak karen kepuncak bukan tanpa alasan, karena alasan nath ingin membuat sang adik senang dan kembali bersemangat untuk menjalani hidup.

\section{Kebersamaan}

Kebersamaan adalah menciptakan kedekatan antar sesama manusia kebersamaan bisa dirasakan dalam bentuk kekeluargaan persabahabatan dan lain-lain. Seperti pada kutipan berikut ini.

\begin{abstract}
Malam itu mereka berkumpul dalam beranda rumah tepi pantai milik keluarga dodit. Ada pengurus rumah yangg mengurusisegala kebutuhan mereka di sana.selesai bermain di pantai dan mandi, meraka bisa langsung berkumpul didi beranda yang menghadap pantai untuk acara barbekyu. Kenny dan rama heboh seperti bias, sementara dodit selalu tidak sengaja menimbulan hal lucu yang mengundang tawa teman-temannya. Nath memetik gitar, memberikan musik latar pada tiap kebodohan dodit hingga tawa mereka semua tak putus-putus. (hlm, 56-57)
\end{abstract}

Pada kutipan di atas menjelaskan tentang nath, karen, dodit, kenny, rama, gabi, keysha dan nadine delapan sekawan yang biasa memiliki kebersamaan dari dulu hingga sekang, persahabatan yang bodoh dan sering bertengkar tetapi mereka saling peduli dan saling mendukung satu sama lain.

\section{KESIMPULAN}

Berdasarkan hasil analisis data yang sudah dilakukan maka dapat ditarik kesimpulan sebagai berikut. Nilai moral yang terdapat dalam novel complicated karya theresia terdiri dari tiga moral yaitu : (1) Wujud aspek moral tokoh-tokoh dalam hubungan manusia dengan tuhan terdiri dari: Senantiasa berdoa kepada tuhan dan bersyukur(2) Wujud aspek moral tokohtokoh hubungan manusia dengan diri sendiri terdiri dari : pintar, jujur, bertanggung jawab, kesedihan, dan kemarahan.(3) Wujud nilai moral tokoh-tokoh hubungan manusia 
dengan masyarakat terdiri dari : peduli sesama, meminta maaf, dan kebersamaan.

\section{SARAN}

Adapun saran-saran yang dapat dikemukakan adalah sebagai berikut.

1) Bagi para pembaca, diharapkan dapat menjadikan penelitian ini sebagai bahan masukan khususnya mengenai tinjauan sosiologi sastra yang membahas tentang aspekaspek moral.

2) Bagi peneliti lainnya, di harapkan dapat menjadikan penelitian ini sebagai bahan acuan dalam melakukan penelitian sastra, khususnya mengenai usnsur sosiologi sastra yang membahas tentang aspek moral yang terdapat di dalam sebuah karya sastra.

3) Bagi penikmat sastra diharapkan novel Complicated karya Theresia dapat menjadi acuan dalam mengambil hikmah yang terjadi didalam kehidupan sehari-hari.

\section{DAFTAR PUSTAKA}

Adi, I. R. (2016). Fiksi Populer Teori \& Metode Kajian. Yogyakarta: Pustaka Pelajar.

Agustina, J. (2017). Citra Tokoh dalam Novel Mekar Menjelang Malam Karya Mira.W. 32-43.

Anwar, A. (2012). Teori Sosial sastra. Yogyakarta: Ombak Data.

Arikunto, S. (2010). Prosedur Penelitian Suatu Pendekatan Praktik. Jakarta: PT Rineka Cipta.

Bahasa, K. B. (2015). Depertemen Pebdidikan. Jakarta: Kompas Gramedia.

Biyantari, L. A. (2009). Aspek Moral Dalam Novel Harimau! Karya Mochtar Lubis :Tinjauan Semiotik. 1-23.

Endraswara, S. (2013). Metodelogi Penelitian Sastra Epistemologi, model, Teori dan Aplikasi. Yogyakarta: CAPS.

Ismawati, E. (2013). Pengajaran Sastra . Yogyakarta: Ombak.
Kurniawan, H. (2012). Teori Metode dan Aplikasi Sosiologi Sastra . Yogyakarta: Graha Ilmu.

Mayasari, W. G. (2010). Aspek Moral Dalam Novel Midah Simanis Bergigi Emas Karya Pramoedya Ananta Toer :Tinjauan Sosiologi Sastra. 1-21.

Nasional, D. P. (2015). Kamus Besar Bahasa Indonesia Pusat Bahasa. Jakarta: PT Gramedia Pustaka Utama.

Nurgiyantoro, B. (2012). Teori Pengkajian Fiksi. Yogyakarta: Universitas Gadjah Mada.

Priyatni, E. T. (2012). Membaca Sastra Dengan Ancangan Literasi Kritis. Jakarta: PT Bumi Aksara.

Ratna, N. K. (2013). Paradigma Sosiologi Sastra. Yogyakarta: Pustaka Pelajar.

Sugiyono. (2015). Metode Penelitian Kuantitatif, Kualitatif dan $R \& D$. Bandung: Alfabeta.

Theresia. (2019). Complicated. Jakarta: PT Gramedia. 